\begin{tabular}{l|l|l} 
Vurnal Eksplorasi Akuntansi (JEA) & e-ISSN : 2656-3649 (Online) \\
Vol. 3, No 3, Agustus 2021, Hal 687-704 & htt/jea.ppj.unp.ac.id/index.php/jea/index
\end{tabular}

\title{
Pengaruh Tunneling Incentive, Mekanisme Bonus, dan Leverage Terhadap Keputusan Melakukan Transfer Pricing pada Perusahaan Manufaktur, Perkebunan, dan Pertambangan
}

\author{
Al Hafizil Azhar ${ }^{*}$, Mia Angelina Setiawan ${ }^{2}$ \\ ${ }_{1,2}$ Fakultas Ekonomi, Universitas Negeri Padang \\ *Korespondensi: alhafiz751@gmail.com
}

\begin{abstract}
The purpose of this study was to examine the effect of tunneling incentives, bonus mechanisms and leverage on transfer pricing decisions. This research includes causative research. The population used in this study are manufacturing, mining and plantation companies listed on the Indonesia Stock Exchange for the 2015-2019 period. The sampling technique used in this research is purposive sampling technique. There are 54 manufacturing, mining and plantation companies that are used as research samples. The type of data used is secondary data obtained from the official website of the Indonesia Stock Exchange and the official website of each company. The analytical method used is a quantitative method. The results show that the bonus and leverage mechanisms do not have a positive effect on transfer pricing, but the tunneling incentive variable has a positive effect on transfer pricing.
\end{abstract}

Keywords: tunneling incentive; bonus mechanism; leverage; transfer pricing.

How to cite (APA $6^{\text {th }}$ style)

Al, A. A., \& Setiawan, M. A. (2021). Pengaruh Tunneling Incentive, Mekanisme Bonus, dan Leverage Terhadap Keputusan Melakukan Transfer Pricing pada Perusahaan Manufaktur, Perkebunan, dan Pertambangan. Jurnal Eksplorasi Akuntansi. 3(3). 687704.

\section{PENDAHULUAN}

Pesatnya perkembangan perekonomian saat ini yang dapat memberikan suatu pengaruh pada pola bisnis dan sikap para pelaku bisnis dengan tanpa mengenal batas negara, yang akan berdampak pada perusahaan multinasinonal dalam pengenaan tarif pajak yang berlaku di setiap negara. Adanya perbedaaan tarif pajak ini membuat perusahaan multinasional akan melakukan praktik transfer pricing. Perusahaan multinasional merupakan perusahaan yang dimana operasinya tidak hanya berpusat disatu negara saja, tetapi juga dibeberapa negara. Transaksi yang terjadi pada perusahaan multinasional berupa penjualan barang antar perusahaan yang berelasi atau mempunyai hubungan istimewa. Perusahaan akan sulit untuk menentukan harga atas transaksi penjualan antar perusahaan apabila perusahaan memiliki anak perusahaan diberbagai negara, oleh sebab itu perusahaan akan melakukan praktik transfer pricing agar dapat menentukan harga atas transaksi-transaksi tersebut (Asyhinta et al 2019).

Penentuan harga atas berbagai transaksi antar anggota atau devisi tersebut lazim disebut dengan transfer pricing Mangoting (2000) dalam Marfuah dan Azizah (2014). 
Menurut Sumarsan (2015:231) transfer pricing merupakan jumlah uang yang dikeluarkan untuk setiap transfer produk baik itu barang atau jasa dari pusat pertanggungjawaban yang satu ke pusat pertanggungjawaban yang lainnya atau sebaliknya. Jadi, transfer pricng menetapkan secara tegas hak dari masing-masing manajer pusat pertanggungjawaban untuk mendapatkan laba. Kasus transfer pricing atau harga transfer pada tahun 2018 meningkat cukup signifikan dibandingkan dengan tahun 2017. Dalam laporan yang mencakup 89 yurisdiksi, 2018 Mutual Agreement Procedure (MAP) statistics, Organisation for Economic Co-operation and Development (OECD) mencatat jumlah sengketa transfer pricing naik 20\%, jumlah ini lebih tinggi dibandingkan dengen sengketa lainnya yang hanya pada kisaran 10\%. OECD juga mengatakan kebanyakan otoritas pajak menutupi banyak kasus dibandingkan dengan sebelumnya (ekonomi.bisnis.com.2019).

Praktek transfer pricing telah banyak dilakukan dibeberapa perusahaan multinasional seperti Google, Starbucks, dan Amazon. Contohnya pada perusahaan Starbucks dimana pada tahun 2011 mereka mengkalim bahwa telah mengelami kerugian sejak tahun 2008, padahal sebenarnya mereka telah mendapatkan penjualan sebesar £112 juta atau sekitar sebesar Rp1,7 triliun. Sepanjang beroperasi di Inggris, sebagian besar keuntungan Starbucks telah dialihkan dari Inggris ke perusahaan cabang di Belanda dalam bentuk royalti. Starbucks menyatakan telah mengalami penuruanan pendapatan dengan pihak Belanda. Tetepi pihak uni Eropa justru menilai adanya praktek transfer pricing yang telah dilakukan oleh Starbucks. Barford (2013) dalam Noviastika (2016).

Banyak kasus transfer pricing di Indonesia terjadi pada perusahaan menufaktur, perkebunan, dan pertambangan. Dari sektor pertambangan, salah satunya pada perusahaan pertambangan batu bara, memang sudah menjadi salah satu sektor yang selalu menjadi perhatian bagi pemerintah Indonesia.. Salah satunya terjadi pada PT Adaro sejak tahun 20092017 melalui anak perusahaannya di Singapura yaitu Coaltrade Services International telah membuat skema harga transfer. (m.merdeka.com). Berdasarkan uraian kasus ini memperlihatkan bahwa transfer pricing merupakan salah satu skema yang sangat rawan untuk dijadikan jalan pintas dalam hal memperoleh laba (Merdeka.com, 2019).

Indonesia merupakan negara pemain kunci dalam industri petambangan batu baru. Hingga saat ini indonesia merupakan salah satu produsen penghasil batu bara terbesar kelima di dunia. Pada tahun 2017, indonesia menghasilkan batu bara sebesar 7,2\% dari total produksi dunia. Data menurut Badan Pusat Statistik (BPS), selama tahun 2014 sampai tahun 2018 industri pertambangan batu bara lignat rata-rata menyumbang 2,3\% terhadap Produk Domestik Bruto (PDB) pertahunnya atau sebesar Rp235 triliun. Dibalik tingginya nilai ekonomi yang dihasilkan oleh industri pertambangan batu bara, ternyata sangat minim kontribusi yang dapat masuk ke kas negara. Dari kasus tersebut industri pertambangan ini mengindikasikan bahwa adanya motivasi praktik transfer pricing yang dilakukan beberapa perusahaan pertambangan khususnya industri batu bara dengan tujuan untuk memaksimalkan laba yang dihasilkan (katadata.co.id, 2019).

Dari beberapa kasus diatas dapat disimpulkan bahwa transfer pricing merupakan salah satu skema yang dilakukan perusahaan untuk memperoleh laba yang besar, dan hal tersebut menjadikan transfer pricing sebagai hal yang sangat perlu diteliti untuk dapat mengetahui faktor-faktor yang mempengaruhi transfer pricing. Menurut Jumaidi et al (2017) skema yang bisa dilakukan oleh perusahaan multinasional dalam praktek transfer pricing adalah dengan cara mengalihkan keuntungan mereka dari negara yang tarif pajaknya tinggi ke negara yang tarif pajaknya rendah. Berbagai penelitian yang sudah dilakukan tentang keputusan perusahaan untuk melakukan transfer pricing. Penelitian tersebut menggunakan variabel karekteristik yang berbeda sehingga hasil penelitiannnya pun berbeda.

Ada beberapa alasan perusahaan mengambil keputusan untuk melakukan transfer pricing. Salah satu alasan perusahaan melakukan transaksi transfer pricing adalah melalui 
tunneling incentive. Menurut Jumaidi et al (2017) tunneling incentive merupakan suatu kegiatan yang dilakukan oleh pemegang saham mayoritas yang mentransfer aset dan laba perusahaan hanya untuk keuntungan mereka sendiri, namun beban yang dikeluarkan dari kegiatan tersebut juga ditanggung oleh pemegang saham minoritas. Dengan adanya pemindahan aset yang dari suatu perusahaan ke perusahaan lainnya baik yang memiliki hubungan istimewa ataupun tidak, apalagi dilakukan antara negara yang memiliki tarif pengenaan pajak yang berbeda yang dimana dapat menimbulkan praktek transfer pricing yang mengakibatkan negara yang mempunyai tarif pajak yang lebih tinggi akan mengalami kerugian.

Selain tunneling incentive faktor lain yang memungkinkan mempengaruhi perusahaan untuk melakukan transfer pricing adalah mekanisme bonus. Mekanisme bonus pada hakekatnya berdasarkan pada besarnya laba yang didapat oleh perusahaan. Dimana sistem pada pemberian kompensasi bonus ini akan memberikan dampak atau pengaruh terhadap manajemen dalam hal merekayasa laba. Penelitian yang dilakukan oleh Fitri et al (2019) hasil penelitiannya menemukan bahwa mekanisme bonus berpengaruh positif dan signifikan terhadap perusahaan melakukan transfer pricing. Namun penelitian yang dilakukan oleh Indriaswari \& Aprilia (2017) dan Asyhinta et.al (2019) menemukan bahwa mekanisme bonus tidak memiliki pengaruh signifikan pada keputusan perusahaan dalam melakukan transfer pricing.

Selain tunneling incentive dan mekanisme bonus faktor lain yang mampu mempengaruhi keputusan perusahaan untuk melakukan transfer pricing adalah leverage. Menurut Praditasari (2017) dalam Arianandini \& Ramantha (2018) leverage merupakan perbandingan yang menggambarkan besarnya utang yang digunakan oleh perusahaan untuk pembiayaan dalam menjalankan aktivitas operasinya. Penelitian yang dilakukan oleh Rahayu et al (2020) menyatakan bahwa leverage tidak berpengaruh terhadap keputusan transfer pricing. Namun penlitian yang dilakukan oleh Bela Pratiwi (2018) menunjukkan bahwa leverage berpengaruh signifikan terhadap tranfer pricing, dan penelitian Shodiq et al (2017) menemukan bahwa leverage berpengaruh positif tidak signifikan terhadap transfer pricing.

Berdasarkan uraian di atas, penelitian termotivasi untuk melakukan penelitian ini karena dalam perkembangan penggunaan skema transfer pricing terdapat motivasi lain selain pajak yang mempengaruhi pihak manajeman untuk melakukan praktek transfer pricing dalam rangka menaikkan laba pada periode berjalan. Penelitian ini menggunakan sampel perusahaan manufaktur, perkebunan, dan pertambangan yang terdaftar pada Bursa Efek Indonesia dari tahun 2015 sampai dengan 2019 Alasan peneliti untuk memilih perusahaan manufaktur, perkebunan, dan pertambangan karena sektor ini merupakan sektor yang memiliki banyak kasus transfer pricing. Perbedaan penelitian ini dengan penelitian sebelumnya adalah yaitu variabel pada penelitian ini tunneling incentive, struktur mekanisme bonus dan leverage. Lalu, sampel perusahaan yang digunakan merupakan perusahaan manufaktur, perkebunan, dan pertambangan yang digunakan dalam periode tahun 2015 sampai dengan tahun 2019 .

\section{REVIU LITERATUR DAN HIPOTESIS}

\section{Teori Keagenan (Agency theory)}

Teori keagenan merupakan hubungan yang muncul ketika adanya pihak (prinsipal) memberikan mandat dan tanggung jawab kepada pihak lain (agen) untuk menjalankan dan mengambil keputusan sesuai dengan kepentingan prinsipal (Jansen dan Meckling, 1976). Di dalam teori agensi ada dua pihak yang terlibat, yaitu pihak prinsipal dan pihak agen. Dimana pihak agen adalah pihak yang menerima mandat, kewenangan dan bertanggung jawab kepada pihak prinsipal. Sedangkan pihak prinsipal adalah pihak yang memberikan mandat dan kewenangan kepada pihak lain. 
Dalam teori keagenan terjadinya konflik diakibatkan oleh adanya ketidakcocokan informasi, yang menyebabkan seorang manajer mempunyai informasi yang jauh lebih lengkap dibandingkan dengan pemegang saham. Seorang manajer selain diberikan kekuasaan untuk mengelola perusahaan, manajer juga diberikan bonus apabila target yang diinginkan pemegang saham tercapai. Sifat struktur kepemilikan suatu perusahaan juga dapat mempengaruhi masalah keagenan. Dimana apabila suatu perusahaan memiliki struktur kepemilikan terkonsentrasi dengan kata lain ada satu pihak yang mempunyai kendali atas perusahaan, maka masalah keagenan akan berbeda, yaitu dimana masalah manajer dengan pemegang saham mengalami perubahan menjadi lebih luas yaitu, pemegang saham mayoritas dengan pemegang saham minoritas (Noviastika et al, 2016).

Hubungan teori agensi dengan transfer pricing apabila masalah asimetri berubah menjadi masalah antara pemegang saham mayoritas dengan pemegang saham minoritas dimana pemegang saham mayoritas telah menamkan modal dan saham yang besar oleh karena itu mereka akan mengharapkan return dan dividen yang besar pula.

\section{Teori Akuntansi Positif}

Watts dan Zimmerman (1990) menyebutkan bahwa teori akuntasni positif menjelaskan bagaimana kebijakan akuntansi menjadi suatu problematika bagi pihak-pihak yang berkepentingan dan perusahaan dengan laporan keuangan. Teori ini juga digunakan untuk memprediksi kebijakan akuntansi yang seharunya dipilih perusahaan pada saat kondisi tertentu. Dimana manajer melakukan seleksi terhadap kebijakan akuntansi yang lebih optimal dan cocok untuk tujuan tertentu. Menurut Setijaningsih, (2012) teori akuntansi positif pada prinsipnya beranggapan bahwa tujuan dari teori akuntansi adalah untuk menjelaskan dan memprediksi praktik-praktik akuntansi, yang bermaksud memberikan alasan-alasan terhadap praktik yang diamati.

Teori akuntansi juga harus mampu memprediksi berbagai kejadian praktik akuntansi yang belum dijalankan. Watts dan Zimmerman (dalam Januarti,2004) menjelasakan tujuan teori akuntansi adalah untuk menjelaskan (explanation) dan memprediksi (prediction) praktek akuntansi. Efficient Market Hypothesis (EMH) dan Capital Asset Pricing Model (CAPM) memiliki peran penting sebagai pengembangan teori akuntansi positif. EMH menghasilkan literatur empiris yang menjelaskan tentang hubungan antata harga saham dengan laba akuntansi, hubungan antara harga saham dengan perubahan dalam prosedur akuntansi, EMH juga menyebabkan perubanhan yang sesuai bagi pengaturan pengungkapan (disclosure) perusahaan. Sedangkan CAPM mengindikasikan faktor-faktor yang dapat mempengaruhi nilai pasar dari sekuritas, khususnya ecpected cash flow dan resiko bawaan.

\section{Transfer Pricing}

Menurut Hansen dan Mowen (2009:587-588) harga transfer (transfer pricing) merupakan harga yang dibebankan untuk suatu komponen (barang atau jasa) dari devisi penjual kepada divisi pembeli pada perusahaan yang sama. Keputusan harga transfer dihitung dengan ada tidaknya suatu transaksi penjualan kepada pihak yang memiliki hubungan istimewa. Menurut Hansen dan Mowen (2009:590) di dalam praktik penetapan harga transfer ada beberapa kebijakan yang dapat digunakan, yaitu harga transfer berdasarkan pasar, harga transfer berdasarkan biaya, dan harga transfer yang dinegosiasikan.

\section{Tunneling Incentive}

Menurut Hartati et al (2015) tunneling incentive suatu tindakan dari pemegang saham pengendali yang menstransfer aset dan laba perusahaan demi keuntungannya sendiri, namun beban akan ditanggung juga oleh pemegang saham non pengendali. Ada beberapa contoh tunneling yaitu, menjual aset-aset perusahaan kepada perusahaan lain dengan harga yang 
dibawah harga pasar, tidak memberikan dividen, dan memilih anggota keluarga untuk menduduki posisi penting di dalam perusahaan (Putri dan Saifudin, 2018).

Adanya tunneling ini dikarenakan adanya masalah keagenan yaitu, antara pemegang saham mayoritas dan pemegang saham minoritas. Secara sederhana, jika pemegang saham mayoritas memiliki kepemilikan yang besar, atau dengan kata lain mereka telah menanamkan modalnya yang juga besar ke dalam perusahaan tersebut. Ketika akan dibagikannya dividen oleh perusahaan tersebut ke pemilik pemegang saham minoritas, maka para memegang saham mayoritas akan lebih memilih untuk melakukan transfer pricing dengan cara memindahkan atau menstranfer kekayaan perusahaan untuk kepentingannya sendiri daripada membagikan dividen ke pemegang saham minoritas (Pratiwi, 2018).

\section{Mekanisme Bonus}

Menurut Rafgia (2017), juga mengatakan bahwa mekanisme bonus adalah pemberian kompensasi tambahan atau pegahargaan yang diberikan kepada pegawai perusahaan atas kinerja yang baik dan pencapaian target perusahaan. Cara yang paling sering digunakan oleh perusahaan dalam memberikan kompensasi adalah dengan mekanisme bonus berdasarkan laba. Jadi, karena dasar ini lah manajer atau direksi dapat memenipulasi laba tersebut untuk memaksimalkan bonus yang akan diterimanya.

Dalam menjalankan tugasnya, dewan direksi cenderung akan menunjukkan kinerja yang baik kepada pemilik perusahaan untuk memperoleh penghargaan. Penghargaan itu bisa berupa bonus yang diberikan berdasarkan kinerja dewan direksi dalam mengelola perusahaan. Jadi pemilik perusahaan tidak hanya memberikan bonus kepada dewan direksi yang telah berhasil menghasilkan laba untuk submitnya atau divisi, namun juga kepada dewan direksi yang bersedia untuk bekerjasama demi kebaikan dan keuntungan perusahaan baik secara keseluruhan (Mispiyanti, 2015).

\section{Leverage}

Menurut Rezky dan Fachrizal (2018), leverage didefinisikan sebagai rasio yang menunjukkan sebarapa besarnya utang yang dimiliki perusahaan dalam pembiayaan aktivitas operasinya. Penambahan utang akan berakibat munculnya beban bunga yang harus dibayarkan oleh perusahaan, dan juga akan mengurangai laba yang dihasilkan perusahaan.

Leverage dapat diartikan sebagai nilai buku dari total hutang jangka panjang yang dibagi dengan total aktiva. Leverage berkemungkinan memiliki hubungan positif dengan risiko, hal itu karena semakin besar leverage maka akan semakin besar kewajiban membayar dalam jangka panjang. Leverage mengukur seberapa besar perusahaan dibiayai dengan utang. Pada saat leverage tinggi, maka laba yang dihasilkan akan semakin berkurang karena untuk menutupi pembayaran pokok pinjaman dan pembayaran bunga. Namun sebaliknya, jika tingkat leverage perusahaan rendah maka kecil pula kemampuan perusahaan untuk pembayaran pokok pinjaman dan bunganya (Ja'far, 2017).

\section{Pengaruh Tunneling Incentive Terhadap Keputusan Transfer Pricing}

Tunneling incentive merupakan suatu tindakan dari pemegang saham pengendali yang menstransfer aset dan laba perusahaan demi keuntungannya sendiri, namun beban akan ditanggung juga oleh pemegang saham non pengendali (Hartati et al, 2015). Ada beberapa contoh tunnleing yaitu, menjual aset-aset perusahaan kepada perusahaan lain dengan harga yang dibawah harga pasar, tidak memberikan dividen, dan memilih anggota keluarga untuk menduduki posisi penting di dalam perusahaan (Putri dan Saifudin, 2018). Dengan adanya praktik transfer pricing ini pemegang saham non pengendali akan sangat dirugikan. Dimana, dividen yang akan mereka terima hanya sedikit atau tidak adanya pembagian dividen karena 
perusahaan mengalami kerugian akibat biaya yang terlalu besar akibat adanya harga jual produknya dibawah harga pasar (Asyhinta, 2019).

Di dalam teori agensi, konflik agensi terjadi antara pemegang saham mayoritas (majority shareholders) dengan pemegang saham minoritas (minority shareholders). Dimana konflik ini terjadi akibat adanya pemegang saham mayoritas memaksakan keinginannya kepada manajer untuk memenuhi kepentingan pribadi kepentingan pemegang saham mayoritas. Oleh sebab itu, maka perusahaan akan dengan mudah untuk melakukan kebijakankebijakan negatif seperti harga transfer (transfer pricing). Harga transfer akan mudah terjadi melalui suatu upaya untuk memindahkan aset atau laba pada perusahaan, sehingga laba yang dari perusahaan dapat menjadi lebih rendah. Akibat dari pemindahan aset atau laba perusahaan akan berdampak pada penurunan keuntungan yang akan diperoleh para pemegang saham ninoritas. Praktik ini yang dilakukan oleh manajer akibat dari adanya dorongan dari pemegang saham mayoritas yang merupakan salah satu pemicu utama terjadinya praktik transfer pricing. Dengan melakukan tunneling incentive melalui upaya pemindahan tersebut, akan mendorong pemegang saham mayoritas untuk mendapatkan keuntungan yang lebih sehingga mereka akan melakukan praktik transfer pricing.

Mispiyanti (2015) \& Noviastika (2016) menemukan bahwa tunneling berpengaruh signifikan terhadap keputusan perusahaan untuk melakukan transfer pricing. Dapat disimpulkan bahwa pemilik saham mayoritas akan melakukan cara-cara agar mendapatkan laba yang tinggi dan yang akan mengorbankan hak-hak pemegang saham moniritas. Salah satu cara yang akan dilakukannya adalah praktek transfer pricing. Berdasarkan analis dan teori diatas maka dapat dirumuskan hipotseis sebagai berikut:

H1: Tunneling incentive berpengaruh positif terhadap keputusan transfer pricing

\section{Pengaruh Mekansime Bonus Terhadap Keputusan Transfer Pricing}

Mekanisme bonus merupakan suatu komponen perhitungan besarnya jumlah bonus yanng diberikan oleh pemegang saham melalui Rapat Umum Pemegang Saham (RUPS) kepada dewan direksi karena dianggap telah memberikan kinerja yang baik apabila perusahaan memperoleh laba (Suryatiningsih et al, 2019). Mekanisme bonus ditujukan untuk memberikan penghargaan kepada dewan direksi atau manajer. Di dalam menjalan tugasnya, para dewan direksi cenderung ingin menunjukkan kinerja yang baik kepada pemilik perusahaan. Karena apabila para direksi sudah memberikan kinerja yang baik maka, pemilik perusahaan atau pemegang saham akan memberikan suatu penghargaan. Salah satu penghargaan itu bisa berupa bonus yang diberikan kepada dewan direksi.

Mekanisme bonus didasarkan pada bonus plan hyphotesis dalam teori akuntansi positif. Di dalam hipotesis ini menjelaskan bahwa para manajer yang mengambil rencana bonus maka para manajer cenderung untuk memilih prosedur akuntansi dengan perubahan laba yang dilaporkan dari periode masa depan ke periode masa kini. Dikarenakan pemberian bonus ini dapat memicu manajer untuk melakukan perekayasaan laporan keuangan perusahaan agar memperoleh bonus yang maksimal dari pemilik perusahaan. Dengan semakin besarnya keinginan menajemen untuk memperoleh bonus, maka akan semakin besar kecenderungan manajemen untuk membuat keputusan praktik transfer pricing untuk meningkatkan laba.

Di dalam penelitian Refgia et al (2017) menunjukkan bahwa mekansime tidak berpengaruh terhadap keputusan perusahaan untuk melakukan transfer pricing. Hasil yang berbeda yang ditunjukkan oleh penelitian Hartati el al (2015) menunjukkan bahwa mekansime berpengaruh terhadap keputusan perusahaan untuk melakukan transfer pricing. Hal ini membuktikan bahwa pemilik perusahaan akan mempertimbangkan pencapaian laba perusahaan yang telah dicapai secara keseluruhan guna melakukan penialain atas prestasi kinerja direksinya sehingga para direksi akan berusaha untuk memaksimalkan mungkin menaikkan laba secara keseluruhan dengan cara melakukan praktik transfer pricing. 
H2: Mekanisme bonus berpengaruh positif terhadap keputusan transfer pricing

\section{Pengaruh Leverage Terhadap Keputusan Transfer Pricing}

Perusahaan biasanya memiliki berbagai sumber pendanaan dalam menjalakan bisnisnya, salah satu contohnya dengan menggunakan utang. Leverage adalah suatu perbandingan antara nilai total kewajiban dengan nilai total aset perusahaan. Semakin tinggi suatu hutang perusahaan maka akan semakin tinggi pula suatu beban bunga perusahaan yang akan ditanggung, tingginya beban bunga tersebut akan dapat mengurangi laba yang akan diperoleh perusahaan.

Di dalam teori akuntansi positif adanya perbedaan antara kreditur dengan manajemen. Untuk memperkecil asimetri informasi, maka pengelolaan perusahaan harus diawasi dan dikendalikan untuk memastikan bahwa pengelolaan dilakukan dengan penuh kepatuhan terhadap berbagai aturan dan ketentuan yang berlaku. Perbedaan kepentingan antara kreditur dan manajemen akan menimbulkan perbedaan akan kebutuhan modal baik secara eksternal ataupun internal yang akan berdampak pada upaya perusahaan akan melakukan transfer pricing. Dimana beban utang yang semakin tinggi akan memicu perusahaan untuk melakukan transfer pricing dengan harapan dapat menekan beban tersebut.

Penelitian yang dilakukan oleh Facrizal dan Rezky (2018) leverage berpengaruh signifikan terhadap keputusan perusahaan untuk melakukan transfer pricing. Perusahaan yang tingkat leverage tinggi akan membayar pajak lebih sedikit, transfer utang dari induk ke anak perusahaan menjadikan seknario struktur utang yang akan menguntungkan perusahaan. Di perkuat dengan penelitian Cahyadi et al (2018), yang menyatakan bahwa leverage berpengaruh positif pada keputusan perusahaan untuk melakukan transfer pricing. Hal ini berarti semakin tinggi tingkat leverage perusahaan maka maka semakin besar insentif peruahaan untuk melakukan transfer pricinng. Berdasarkan uraian di atas maka dapat dirumuskan hipotesis sebagai berikut:

H3: Leverage berpengaruh positif terhadap keputusan transfer pricing

\section{METODE PENELITIAN}

\section{Sampel dan Jenis Penelitian}

Jenis penelitian yang digunakan oleh peneliti ialah penelitian kausatif. Penelitian kausatif berguna untuk menganalisis pengaruh suatu variabel terhadap variabel lainnya. Metode yang digunakan dalam penelitian ini adalah salah metode kuantitatif. Populasi yang digunakan peneliti didalam penelitian ini adalah semua perusahaan manufaktur, pertambangan, dan perkebunan yang terdaftar berturut-turut di BEI selama tahun 2015-2019 secara berturut turut. Sampel peneltian ini berjumlah 54 perusahaan. Metode Pengambilan sampel yang digunakan oleh peneliti adalah metode Purposive Sampling yang ditentukan berdasarkan kriteria tertentu. Kriteria dalam pengambilan sampel seperti:

Tabel 1

Kriteria Pemilihan Sampel

\begin{tabular}{llr}
\hline No. & \multicolumn{1}{c}{ Kriteria } & \multicolumn{1}{c}{$\begin{array}{l}\text { Jumlah } \\
\text { perusahaan }\end{array}$} \\
\hline 1. & $\begin{array}{l}\text { Perusahaan } \\
\text { pertambangan, dan perkebunan yang } \\
\text { terdaftar berturut-turut di BEI selama } \\
\text { tahun 2015-2019 }\end{array}$ & 241 \\
2. & $\begin{array}{l}\text { Perusahaan } \\
\text { pertambangan, dan perkebunan yang }\end{array}$ \\
\hline
\end{tabular}




\begin{tabular}{ll}
\hline tidak mempublikasikan laporan \\
keuangan di BEI secara konsisten \\
selama tahun 2015-2019 \\
3. Perusahaan yang menyajikan laporan \\
keuangan menggunakan mata uang \\
selain rupiah \\
4. $\begin{array}{l}\text { Perusahaan yang mengalami kerugian } \\
\text { pada tahun 2015-2019 } \\
\text { Perusahaan yang memenuhi kriteria } \\
\text { yang telah ditentukan } \\
\text { Total perusahaan sampel (54 x 5) } \\
\text { tahun }\end{array}$ \\
\hline
\end{tabular}

\section{Jenis dan Sumber Data}

Jenis data yang digunakan dalam penelitian ini adalah data dokumenter, dimana data yang diambil berupa laporan keuangan dan laporan tahunan (annual report) perusahaan manufaktur, pertambangan, dan perkebunan yang terdaftar di Bursa Efek Indonesia (BEI) pada tahun 2015-2019. Data ini merupakan data yang sifatnya mendukung keperluan data primer. Dalam penelitian ini, data sekunder diperoleh dari website BEI (Bursa Efek Indonesia) www.idx.com.

\section{Variabel Penelitian dan Pengukuran}

\section{Transfer Pricing}

Harga transfer (transfer pricing) merupakan harga pada setiap produk atau jasa dari satu devisi yang ditransfer ke devisi yang lain dalam satu perusahaan yang sama atau antar perusahaan yang mempunyai hubungan istimewa. Transfer priicng dihitung dengan menggunakan pendekatan dikotomi, yaitu dengan melihat keberadaan penjualan kepada pihak yang memiliki hubungan istimewa. Penjualan kepada pihak yang memiliki hubungan istimewa diindikasikan melakukan praktik transfer pricing. Harga yang ditetapkan dalam penjualan terhadap pihak yang memiliki hubungan istmewa atau berelasi biasanya menggunakan harga yang tidak wajar, biasa dengan menurunkan atau menaikkan harga. Sehingga perusahaan yang melakukan penjualan kepeda pihak yang memiliki hubungan istimewa, maka akan diberi nilai 1 (satu), sedangkan yang tidak diberi nilai 0 (nol) (Mispiyanti, 2015).

\section{Tunneling Incentive}

Tunnneling incentive diproksikan dengan persentase kepemilikan saham yang di atas $20 \%$ sebagai pemegang saham pengendali. Hal ini terdapat dalam PSAK No. 15 yang menjelaskan tentang pengaruh signifikan yang dimiliki oleh pemegang saham dengan persentase $20 \%$ atau lebih (Yuniasih, 2012). Variabel tunneling incentive diproksikan dengan perhitungan:

$$
\mathrm{TNC}=\frac{\text { Jumlah Kepemilikan Saham Terbesar }}{\text { Jumlah Saham Beredar }}
$$

\section{Mekanisme Bonus}

Mekansime bonus (bonus plan) merupakan strategi perhitungan dalam akuntansi untuk memaksimalkan dalam penerimaan kompensasi oleh dewan direksi dengan cara menimgkatkan laba perusahaan secara keseluruhan. Mekanisme bonus dihitung dengan rumus profitabilitas, yaitu berdasarkan dengan persentase pencapaian laba tahun $\mathrm{t}$ terhadap laba bersih tahun - $t$ (Hartati et al, 2015). Varibael mekanisme bonus diproksikan dengan Indeks 
Trend Laba Bersih (ITRENDBL). Pengukuran variabel ini menggunakan skala rasio dengan rumus sebagai berikut:

\author{
ITRENDBL $=\underline{\text { Laba Bersih Tahun } \mathrm{t}}$ \\ Laba Bersih Tahun t-1
}

\title{
Leverage
}

Leverage merupakan perhitungan besarnya aset yang dibiayai olehutang-utang yang berasal dari kreditur, bukan dari investor ekuitas akan meminimalkan pajak perusahaan Richardson et al (2013) dalam Deanti (2017). Variabel leverage dikur dengan membagi total kewajiban jangka panjang dengan total aset perusahaan (Richardson et al, 2013 dalam Deanti, 2017).

\section{Leverage $=\underline{\text { Total Kewajiban Jangka Panjang }}$ \\ Total Aset Perusahaan}

Adapun model regresi logistik dalam penelitian ini ditunjukkan dalam persamaan sebagai berikut:

$$
\mathrm{Y}=\alpha+\beta 1(\mathrm{TNC})+\beta 2(\mathrm{BONUS})+\beta 3(\mathrm{LVR})+\mathrm{e}
$$

Keteragan:

$\mathrm{Y}=$ Transfer Pricing (Y), 1 untuk perusahaan yang melakukan transaksi ke pihak yang memiliki hubungan istimewa, 0 untuk perushaan yang menjalankan transaksi ke pihak yang tidak memiliki hubungan istimewa.

$\alpha \quad=$ Konstanta

ß1. ß2. B3 = Koefisien Regresi

TNC= Tunneling Incentive

BONUS = Mekanisme Bonus

LVR = Leverage

$\mathrm{e} \quad=$ Error

HASIL DAN PEMBAHASAN

Analisis Statistik Deskriptif

Tabel 2

Descriptive Statistics

\begin{tabular}{llrrrr}
\hline & N & Minimum & Maximum & \multicolumn{1}{c}{ Mean } & Std. Deviation \\
\hline TNC & 270 & .1017 & .9266 & .568799 & .2154416 \\
BONUS & 270 & .0022 & 25.6262 & 1.298143 & 1.7583117 \\
LVR & 270 & .0032 & .6781 & .124400 & .1233204 \\
Y & 270 & 0 & 1 & .59 & .492 \\
Valid N & & & & & \\
(listwise) & 270 & & & & \\
& & & & & \\
\hline
\end{tabular}

Sumber: Hasil Olah Data SPSS 2021

Berdasarkan tabel 2 diperoleh bahwa pada variabel transfer pricing (Y) yaitu 1 untuk perusahaan yang melakukan transaksi ke pihak yang memiliki hubungan istimewa dan 0 untuk perusahaan yang menjalankan transaksi ke pihak yang tidak memiliki hubungan 
istimewa. Pada variabel TNC diperoleh nilai minimum sebesar 0,1017 dan nilai maksimum sebesar 0,9266, dengan standar deviasi sebesar 0,2154416. Adapun rata-rata variabel TNC sebesar 0,568799 atau $56 \%$. Hal itu menunjukkan bahwa $56 \%$ perusahaan yang memiliki nilai kepemilikan saham besar akan melakukan transfer pricing. Pada variabel BONUS diperoleh nilai minimum sebesar 0,0022 dan nilai maksimum sebesar 25,6262. Adapun rata-rata variabel BONUS sebesar 1,298143 dengan standar deviasi sebesar 1,7583117. Pada variabel leverage (LVR) diperoleh nilai minimum sebesar 0,0032 dan nilai maksimum sebesar 0,6781, dengan standar deviasi sebesar 0,1233204. Adapun rata-rata LVR sebesar 0,124400 atau 12\%. Hal itu menunjukkan bahwa 12\% perusahaan akan menggunakan hutang jangka Panjang untuk membiayai perusahaan akan melakukan transfer pricing.

\section{Uji Frekuensi}

Tabel 3

Hasil Uji Frekuensi

Transfer Pricing

\begin{tabular}{|c|c|c|c|c|c|}
\hline & & Frequency & Percent & $\begin{array}{c}\text { Valid } \\
\text { Percent }\end{array}$ & $\begin{array}{c}\text { Cumulative } \\
\text { Percent }\end{array}$ \\
\hline \multirow[t]{4}{*}{ Valid } & $\begin{array}{l}\text { perusahaan yang } \\
\text { menjalankan transaksi }\end{array}$ & & & & \\
\hline & $\begin{array}{l}\text { ke pihak yang tidak } \\
\text { memiliki hubungan } \\
\text { istimewa }\end{array}$ & 110 & 40.7 & 40.7 & 40.7 \\
\hline & $\begin{array}{l}\text { perusahaan yang } \\
\text { melakukan transaksi ke } \\
\text { pihak yang memiliki } \\
\text { hubungan istimewa }\end{array}$ & 160 & 59.3 & 59.3 & 100.0 \\
\hline & Total & 270 & 100.0 & 100.0 & \\
\hline
\end{tabular}

Data yang digunakan dalam penelitian ini berjumlah 270 sampel perusahaan. Berdasarkan tabel 3 di atas menunjukkan distribusi frekuensi untuk variabel transfer pricing ditunjukkan dengan adanya transaksi penjualan pihak yang memiliki hubungan istimewa. Dari total 270 sampel perusahaan pada tahun 2015-2019, terdapat 110 sampel yang tidak melakukan transfer pricing atau sekitar $40,7 \%$ dan sisanya sebesar 160 sampel perusahaan atau sekitar 59,3 melakukan transaksi transfer pricing. Jadi, dapat disimpulkan bahwa perbandingan tersebut menunjukkan bahwa lebih banyak perusahaan yang terdaftar di BEI khususnya perusahaan manufaktur, pertambangan dan perkebunan yang melakukan transaksi transfer pricing dengan perusahaan yang tidak melakukan transaksi transfer pricing

\section{Hasil Pengujian Regresi}

Menguji Kelayakan Model Regresi

\section{Tabel 4}

Hasil Uji Kelayakan Model Regresi

Hosmer and Lemeshow Test Goodness of Fit Test

\begin{tabular}{lcccc}
\hline Step & Chi-square & Df & & Sig. \\
\hline 1 & 27.489 & & 8 & .001 \\
\hline
\end{tabular}

Sumber: Data Output SPSS (2021) 
Pada tabel 4 diperoleh nilai signifikan hasil uji kelayakan model sebesar 0,001 dengan nilai signifikan $<0,05$ menunjukkan bahwa model regresi yang terbentuk tidak mampu memprediksi nilai observasi dengan baik dan kurang cocok dengan data observasinya, sehingga model regresi yang dipergunakan dalam penelitian ini kurang layak dipakai untuk analisis selanjutnya, hal ini karena ada perbedaan yang nyata antara klasifikasi yang diprediksi dengan klasifikasi yang diamati. Namun pada penelitian ini tetap dilanjutkan dengan analisis regresi logistik.

\section{Keseluruhan Model (Overall Model Fit)}

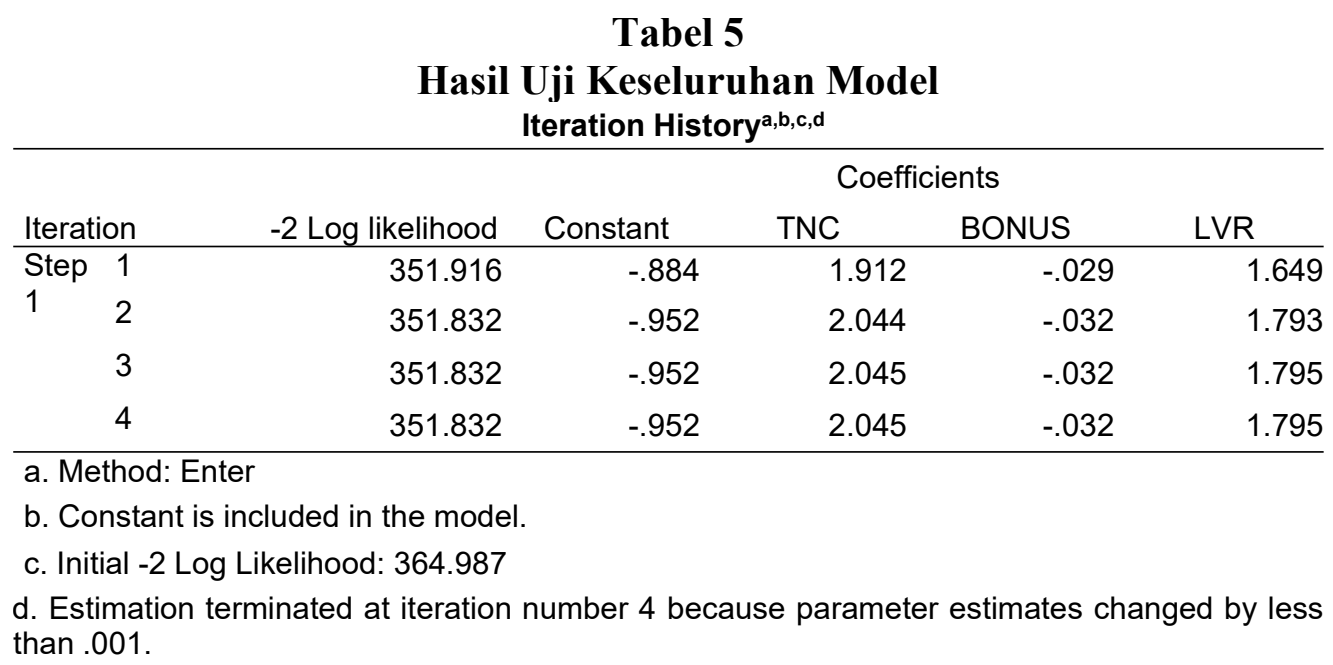

Sumber: Hasil Olah SPSS 2021

Berdasarkan tabel di atas, nilai -2LL awal adalah sebesar 351,916 dan setelah dimasukkan variabel independennya nilai -2LL akhir sebesar 351,832, hal ini menunjukkan adanya penurunan nilai -2LL sebesar 0,084. Penurunan nilai -2LL ini menunjukkan model regresi yang baik atau dengan kata lain model yang telah dihipotesiskan fit dengan data, hal ini berarti variabel bebas seperti tunneling incentive, meknanisme bonus dan leverage akan memperbaiki model fit pada penelitian ini.

Pengujian Simultan (Omnibur Test Of Modal Coeficients)

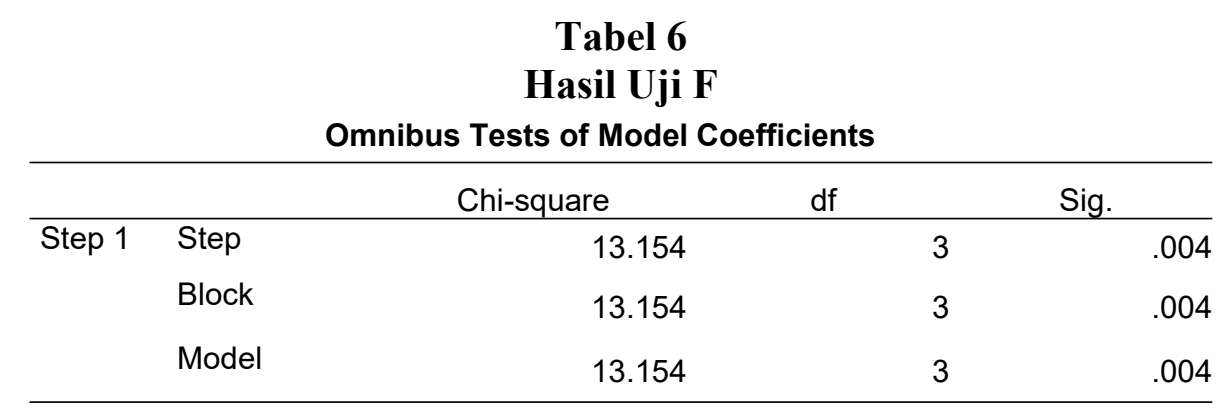

Sumber: Hasil Olah Data 2021

Berdasarkan tabel di atas dapat dilihat bahwa nilai chi Square yang diperoleh adalah sebesar 13,154 dengan nilai signifikan yang dihasilkan adalah sebesar 0,004. Nilai signifikan sebesar $0,004<0,05$, dengan demikian hipotesis penelitian menunjukkan bahwa secara simultan variabel independent yang berupa tunneling incentive, mekanisme bonus dan leverage memiliki pengaruh terhadap variabel dependen yaitu keputusan transfer pricing. 


\section{Koefisien Determinasi $\left(\mathbf{R}^{2}\right)$}

Tabel 7

Hasil Uji Koefisien Determinasi

Model Summary

\begin{tabular}{lrrr} 
Step & -2 Log likelihood & Cox \& Snell R Square & Nagelkerke R Square \\
\hline 1 & $351.832^{\mathrm{a}}$ & .048 & .064 \\
$\begin{array}{l}\text { a. Estimation terminated at iteration number } 4 \text { because parameter estimates changed } \\
\text { by less than } .001 .\end{array}$
\end{tabular}

\section{Sumber: Data Output SPSS (2021)}

Berdasarkan tabel 4.6 di atas diperoleh nilai Cox \& Snell $R$ Square sebesar 0,048, hal ini menunjukkan bahwa besar sumbangan efektif yang diberikan variabel tunneling incentive, mekanisme bonus dan leverage terhadap variabel pransfer Pricing (Y) adalah sebesar 4,8\%. Selanjutnya, nilai Negelkerke $R$ Square dalam model regresi tersebut adalah sebesar 0,064 yang berarti besar variansi variabel transfer pricing (Y) yang dapat dijelaskan oleh variabel tunneling incentive, mekanisme bonus dan leverage adalah sebesar $6,4 \%$, sedangkan sisanya dipengaruhi oleh faktor lain di luar model penelitian ini.

\section{Matriks Klasifikasi}

Tabel 8

\section{Hasil Uji Matriks Klsasifikasi}

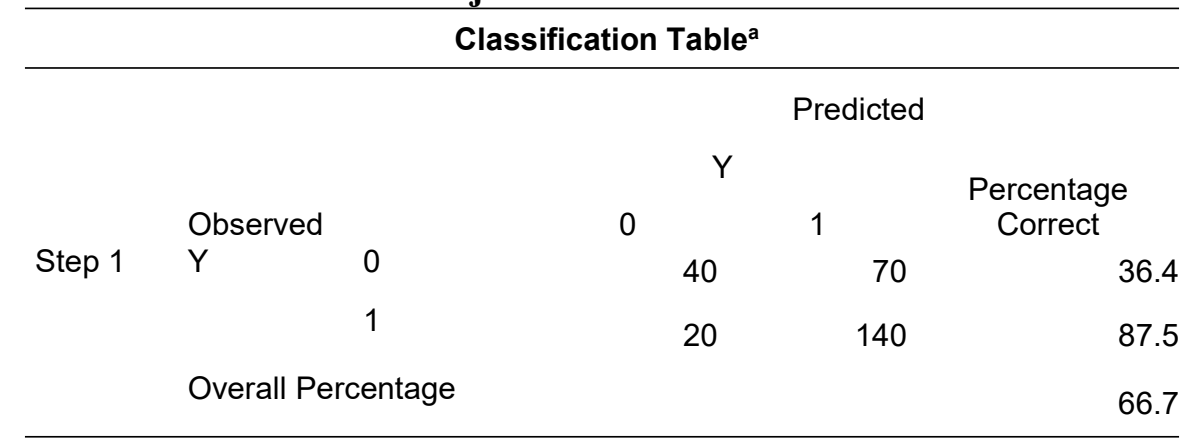

a. The cut value is .500

Sumber: Data Output SPSS (2021)

Berdasarkan tabel klasifikasi diatas frekuensi harapan berdasarkan data empiris variabel dependen, dimana dumlah sampel yang memiliki kategori dengan variabel dependen kode 1 yaitu perusahaan yang melakukan transaksi ke pihak yang memiliki hubungan istimewa sebanyak 140 . Sedangkan untuk kode 0 yaitu untuk perushaan yang menjalankan transaksi ke pihak yang tidak memiliki hubungan istimewa sebanyak 70 . Sehingga nilai overall percentage sebelum variabel independen dimasukkan ke dalam model sebesar $66,7 \%$. 
Tabel 9

Hasil Model Regresi

\begin{tabular}{|c|c|c|c|c|c|c|c|}
\hline \multicolumn{8}{|c|}{ Variables in the Equation } \\
\hline \multirow{5}{*}{ Step $1^{a}$} & & B & S.E. & Wald & df & Sig. & $\operatorname{Exp}(B)$ \\
\hline & TNC & 2.045 & .613 & 11.118 & 1 & .001 & 7.729 \\
\hline & BONUS & -.032 & .071 & .205 & 1 & .651 & .969 \\
\hline & LVR & 1.795 & 1.078 & 2.776 & 1 & .096 & 6.022 \\
\hline & Constant & -.952 & .408 & 5.449 & 1 & .020 & .386 \\
\hline a. Varia & e(s) entere & tep 1: TN & , BONUS, & -VR. & & & \\
\hline
\end{tabular}

Sumber: Data Output SPSS (2021)

Dengan demikian, persamaan regresi yang terbentuk dari hasil analisis regresi logistik tersebut adalah sebagai berikut:

$$
\operatorname{Ln}(\mathrm{Y})=-0,952+2,045 \text { TNC }-0,032 \text { BONUS + 1,795 LVR + e }
$$

\section{Pengujian Hipotesis}

Berdasarkan hasil olahan data pada tabel 9, maka dapat dilihat pengaruh tunneling incentive, mekanisme bonus dan leverage terhadap keputusan perusahaan melakukan transfer pricing secara parsial sebagai berikut:

1) Hipotesis pertama menhyatakan bahwa tunneling incentive berpengaruh positif pada keputusan transfer pricing. Nilai signifikan variabel tunneling incentive (TNC) memiliki koefisien regresi positif sebesar 2,045 dengan tingkat signifikansi 0,001 yang berada dibawah 0,05 (5\%) oleh karena itu hipotesis pertama (Ha1) diterima, sehingga dapat disimpulkan bahwa variabel tunneling incentive (TNC) berpengaruh secara positif signifikan terhadap variabel transfer pricing (Y).

2) Nilai signifikan variabel mekanisme bonus (BONUS) memiliki koefisien regresi negatif sebesar -0,032 dengan tingkat signifikansi diatas $0,05(5 \%)$ yaitu sebesar 0,651 . Oleh karena itu hipotesis kedua (Ha2) ditolak, sehingga dapat disimpulkan bahwa variabel mekanisme bonus (BONUS) tidak berpengaruh secara signifikan terhadap variabel transfer pricing $(\mathrm{Y})$.

3) Nilai signifikan variabel mekanisme leverag (LVR) memiliki koefisien regresi positif sebesar 1,795 dengan tingkat signifikansi diatas 0,05 (5\%) yaitu sebesar 0,096. Oleh karena itu hipotesis kedua (Ha2) ditolak, sehingga dapat disimpulkan bahwa variabel leverage (LVR) tidak berpengaruh secara signifikan terhadap variabel transfer pricing (Y).

\section{PEMBAHASAN}

\section{Pengaruh Tunneling Incentive Terhadap Transfer Pricing}

Hipotesis pertama pada penelitian ini adalah tunnelimg incentive berpengaruh positif pada keputusan transfer pricing. Berdasarkan hasil pengujian hipotesis ditemukan bahwa hipotesis pertama diterima. Sehingga dapat disimpulkan bahwa variabel tunneling incentive (X1) berpengaruh positif terhadap keputusan transfer pricing. Nilai signifikansinya sebesar 0,001 yang signifikan ditingkat 0,01 atau $1 \%$. Hal ini mengindikasikan bahwa semakin besar tunneling incentive dalam perusahaan akan mendorong untuk melakukan perilaku transfer pricing. Hal tersebut mengindikasikan bahwa pemegang saham mayoritas menggunakan hak kendalinya untuk memerintah manajemen dalam melakukan transfer pricing. 
Menurut Santosa \& Suzan (2018) perusahaan yang memiliki kepemilikan saham yang terpusat pada satu pihak akan cenderung untuk melakukan transfer pricing. Apabila pemilik saham memiliki saham yang besar dalam suatu perusahaan, maka mereka juga menginginkan return dan dividen yang besar juga. Jadi, pada saaat dividen akan dibagikan perusahaan pemilik saham mayoritas lebih memilih untuk melakukan transfer pricing dengan cara mentransfer aset atau kekayaan perusahaan untuk kepentingannya sendiri tanpa harus membagi dividen dengan pemilik saham minoritas.

Tunneling lebih dominan dilakukan oleh pemegang saham mayoritas daripada pemegang saham minoritas. Ada beberapa hal tunneling pada struktur kepemilikan terkonsentrasi dapat terjadi. Pertama, insentif dan kemampuan para pemegang saham mayoritas untuk melakukan transaksi-transaksi tertentu. Kedua, perlindungan hak-hak pemegang saham minoritas masib lemah. Ketiga, adanya kekuatan yang dimiliki pemegang saham mayoritas untuk mempengaruhi manajemen dalam membuat keputusan yang bertujuan untuk memekasimumkan kepengantingan pemegang saham mayoritas dan dapat merugikan kepentingan pemegang saham minoritas (Marfuah dan Azizah, 2014).

Berdasarkan teori agensi menjelaskan bahwa masalah keagenan timbul karena adanya konflik antara pemegang saham mayoritas dengan pemegang saham minoritas. Di perusahaan multinasional, manajemen perusahaan dan pemegang saham mayoritas bisa melakukan suatu tindakan yang dapat merugikan pemerintah dan pemegang saham minoritas. Salah satu tindakan tersebut adalah melakukan transaksi pada pihak berelasi untuk mengalihkan aset ataupun keuntungan untuk keluar dari perusahaan dengan cara penetuan harga yang tidak wajar untuk kepentingan pemegang saham mayoritas dan pemegang saham minoritas juga menanggung beban tersebut.

Penelitian ini mendukung penelitian yang dilakukan oleh Hartati (2015) dimana tunneling incentive berpengaruh signifikan terhadap keputusan transfer pricing. transaksi terkait biasa digunakan untuk tujuan transfer kekayaan kepada pemegang saham minoritas daripada pembayaran dividen, hal tersebut dikarenakan perusahaan berkewajiban mendistribusikan dividen kepada perusahaan induk dan pemegang saham minoritas lainnya.

\section{Pengaruh Mekanisme Bonus Terhadap Transfer Pricing}

Hipotesis kedua pada penelitian ini adalah mekansime bonus berpengaruh positif pada keputusan transfer pricing. Berdasarkan hasil uji hipotesis ditemukan bahwa hipotesis kedua ditolak. Maka dapat disumpulkan bahwa variabel mekanisme bonus (X2) tidak berpengaruh positif signifikan terhadap terhadap keputusan transfer pricing. Diperoleh nilai signifikansi untuk variabel mekanisme bonus sebesar 0,651 yang lebih besar dari 0,05. Hasil ini mengindikasikan bahwa ada atau tidaknya mekanisme bonus pada perusahaan tidak dapat mempengaruhi perusahaan untuk melakukan transfer pricing, jadi mekanisme bonus bukanlah alasan yang kuat yang dapat dipakai manajemen untuk mempertimbangkan dalam melakukan transfer pricing.

Hasil penelitian ini mendukung teori akuntansi positif yang menjelaskan para manajer perusahaan dengan rencana bonus cenderung untuk memilih prosedur akuntansi perubahan laba yang dilaporkan dari periode masa depan ke periode masa kini. Para manajer menginginkan imbalan yang tinggi dalam setiap periode. Jika imbalan tersebut bergantung terhadap bonus yang dilaporkan pada pendapatan bersih, maka besar kemungkinan mereka bisa meningkatkan bonus mereka yang akan didapat pada periode tersebut dengan melaporkan pendapatan bersih setinggi mungkin. Tidak berpengaruhnya variabel mekanisme bonus dalam penelitian ini mungkin terjadi karena perusahaan memiliki mekanisme pengawas stakeholder yang baik. Hal tersebut telah diantisipasi dangan keberadaan komite audit yang mempunyai kapasitas dan kemampuan di bidang akuntansi keuangan sehingga dapat menditeksi apabila 
ada kecurangan-kecurangan yang dilakukan oleh manajemen. Dengan adanya komite audit ini tentunya kecurangan di perusahaan dapat diperbaiki.

Penelitian ini juga sejalan dengan penelitian yang dilakukan Indriaswari dan Aprilia (2017) dan Asyhinta et.al (2019) menyatakan bahwa mekanisme bonus tidak berpengaruh terhadap keputusan melakukan transfer pricing. Dimana pemilik perusahaan menginginkan kinerja yang lebih baik dari manajemen untuk meningkatkan keuntungan perusahaan. Sementara itu manajemen juga menginginkan hal yang sama, yaitu keuntungan dalam bentuk bonus untuk kinerja yang telah diberikan kepada perusahan. Meskipun begitu, bukan berarti manajemen akan menghalalkan segalan macam cara dengan cara melakukan kecurangan memanipulasi laporan keuangan dengan memanfaatkan transaksi transfer pricing.

\section{Pengaruh Leverage Terhadap Transfer Pricing}

Hipotesis ketiga pada penelitian ini adalah leverage berpengaruh positif pada keputusan transfer pricing. Berdasarkan hasil uji hipotesis ditemukan bahwa hipotesis kedua ditolak. Maka dapat disimpulkan bahwa variabel leverage tidak berpengaruh signifikan terhadap keputusan transfer pricing. Ini dapat dapat dilihat dari tingkat signifikansi sebesar 0,096 yang lebih besar dari 0,05. Ini mengindikasikan bahwa besar atau tidaknya tingkat leverage perusahaan tidak dapat mempengaruhi perusahaan untuk melakukan transfer pricing. Menurut Shodiq (2017) leverage erat kaitannya dengan kebijakan hutang perusahaan dengan mengadakan hutang antar pihak berelasi untuk menggantikan transfer pricing untuk kepentingan perusahaan seperti perencanaan pajak maupun manajemen laba.

Di dalam teori akuntansi positif, untuk memperkecil asimetri informasi, maka pengelolaan perusahaan harus diawasi dan juga dikendalikan untuk pengelolaan perusahaan telah dilakukan dengan penuh kepatuhan peraturan dan ketentuan yang berlaku. Adanya suatu perbedaan antara kreditur dan perusahaan akan menimbulkan perbedaan akan kebutuhan modal baik itu secara internal maupun secara eksternal yang akan berdampak pada upaya perusahaan untuk melakukan transfer pricing. beban utang yang semakin besar akan memicu perusahaan untuk melakukan transfer pricing dengan harapan dapat menekan beban tersebut.

Hasil penelitian ini sejalan dengan penlitian yang dilakukan oleh Putri (2016) yang menyatakan bahwa semakin tinggi leverage maka semakin besar pembiayaan perusahaan dari kreditor. Hal ini akan berdampak pada pengawasan bank terhadap operasional perusahaan untuk memastikan bahwa pemegamg saham tidak akan melakukan eksprorasi terhadap aset perusahaan. Jika transaksi pihak berelasi sebagai transaksi yang bisa menurunkan nilai aset maka bank sebagai kreditor akan melakukan mengetatkan pengawasan terhadap terjadinya transaksi dengan pihak berelasi di perusahaan. Demikian pula penelitian yang dilakukan oleh Rahayu et al (2020) yang menunjukkan bahwa leverage tidak berpengaruh terhadap transfer pricing.

\section{KESIMPULAN DAN SARAN \\ Kesimpulan}

Penelitian ini bertujuan untuk mengetahui pengaruh tunneling incentive, mekanisme bonus dan leverage terhadap keputusan transfer pricing pada perusahaan manufaktur, pertambangan dan perkebunan yang terdaftar di Bursa Efek Indonesia (BEI) tahun 2015-2019. Berdasarkan hasil analisis data dan pembahasan yang telah dipaparkan pada bab-bab sebelumnya, maka diambil kesimpulan sebagai berikut:

1. Hasil pengujian hipotesis pertama, tunneling incentive berpengaruh positif terhadap keputusan transfer pricing.

2. Hasil pengujuan hipotesis kedua, mekanisme bonus tidak berpengaruh positif terhadap transfer pricing. 
3. Hasil pengujian hipotesis ketiga, leverage tidak berpengaruh positif terhadap transfer pricing.

\section{Keterbatasan dan Saran Penelitian}

Meskipun peneliti telah berusaha merrencang dan mengambangkan penelitian sedemikian rupa, namun masih ada beberap keterbatasan dalam penelitian ini diantaranya sebagai berikut:

1. Nilai Negelkerle $R$ Square yang rendah yaitu hanya sebesar $6,4 \%$ menunjukkan bahwa masih banyak variabel selian tunneling incentive, mekanisme bonus dan leverage yang memiliki kontribusi besar dalam mempengaruhi transfer pricing. Bagi peneliti selanjutnya agar menambahkan variabel lain yang diidentifikasikan dapat mempengaruhi transfer pricing dikarenakan masih rendahnya nilai Negelkerke R Square yang dihasilkan dalam penelitian ini. Variabel tersebut seperti, corporate governance, struktur kepemilikan dan lainnya.

2. Dalam penelitian ini hanya menggunakan sampel dari perusahaan manufaktur, pertambangan dan perkebunan saja, sehingga hasil penelitian ini tidak dapat digeneralisasi untuk sektor perusahaan lainnya. Bagi peneliti selanjutnya dapat menambah kategori perusahaan yang akan dijadikan sampel pada penlitian, misalnya seluruh perusahaan yang terdaftar di Bursa Efek Indonesia agar hasil dari penelitian lebih dapat digenerelasi.

\section{DAFTAR PUSTAKA}

Adaro Tersandung Kasus Dugaan Penggelapan Pajak USD 14 Juta Tiap Tahun Sejak 2009 (https://www.merdeka.com/uang/adaro-tersandung-kasus-dugaanpenggelapan-pajak-usd-14-juta-tiap tahun-sejak-2009.html). Diakses 15 Desember 2020.

Asyhinta, P.J., Agustin, Henri, Afriyenti, Mayar. (2019). Pengaruh Tunneling Incentive, Mekanisme Bonus Dan Exchange Rate Terhadap Keputusan Perusahaan Melakukan Transfer Pricing (Studi Pada Perusahaan Manufaktur Yang Terdaftar di Bursa Efek Indonesia Tahun 2014-2017). Jurnal Eksplorasi Akuntansi, 1(2), Seri A, 572-588.

Ariananadini, Putu Winning \& Ramantha, I Wayan. 2018. Pengaruh Profitabilitas, Leverage, dan kepemilikan Institusional pada Tax Avoidance. E-Jurnal akuntansi Universitas Udayana. Vol.22.3 Maret 2018: 2088-2116.

Astuti Mintorogo \& Syahril Djaddang. 2019. Pengaruh Tunneling Incentive dan Debt Convenant Terhadap Transfer Pricing Yang Dimoderasi Oleh Tax Minimization. Jurnal Akuntansi dan Auditing. Volume 16/No.1 Tahun 2019.

Bella Pratiwi. 2018. Pengaruh Pajak, Exchange Rate, Tunneling Incentive, dan Leverage Terhadap Transfer Pricing. Jurnal Ekobis Dewantara. Vol.1, No.2, Februari 2018.

Cahyadi, Sheirina, Anisa \& Noviari. 2018. Pengaruh Pajak, Exchange Rate, Profitabilitas, dan Leverage Pada Keputusan Melakukan Transfer Pricing. Jurnal Universitas Udayana.

Deanti, L. R.. 2017. Pengaruh Pajak, Intangible Assets, Leverage, Profitabilitas, dan Tunneling Incentive Terhadap Keputusan Transfer Pricing Perusahaan Multinasional Indonesia. Universitas Islam Negeri Syarif Hidayatullah.

Divina Mayzura \& Prima Apriwenni. 2020. Pengaruh Exchange Rate, Multinationally, dan Leverage Terhadap Keputusan Perusahaan Melakukan Praktik Transfer Pricing. Kwik Kian Gie School of Businiess. 2020.

Ekonomi.Bisnis.com. Kasus transfer Pricing Meningkat. (https://ekonomi.bisnis.com/read/20190918/259/1149724/oecd kasus-transfer-pricingmeningkat). Diakses 17 Februari 2020. 
Fitri diah, Nur Hidayat, dan T. Araaono. 2019. The Effect Of Tax Managemen, Bonus Mechanism and Foreighn Ownership On Transfe Pricing Decision. Jurnal Aplikasi Ekonomi Akuntansi dan Bisnis. Vol.1, No.1, Maret 2019, Hal 035-048.

Hansen, Don. R \& Mowen, Maryanne. M. 2009. Akuntansi Manajerial. Edisi 8. Jakarta. Salemba Empat.

Hartati Winda, Desmiyanti dan Julita. (2015). Tax Minimization, Tunneling Incentive dan Mekanisme Bonus Terhadap Keputusan Transfer Pricing Seluruh Perusahaan yang Listing di Bursa Efek Indoneisa. Jurnal SNA, 241-246

Indriaswari, Nuril Yasfiana dan Riski Aprilia. The Influence of Tax, Tunneling Incentive, and Bonus Mechanisms on Transfer Pricing Decision in Manufacturing Companies. The Indonesian Accounting Review. Vol. 7, No. 1, January - June 2017, page 69 - 78.

Irpan. 2010. Analisi Pengahruh Skema Bonus Direksi, Jenis Usaha, Profitabilitas Perusahaan, dan Ukuran Perusahaan Terhadap Earning Manajement: Studi Empiris Pada Perusahaan Manufaktur dan Keungan yang Listing di BEI Pada Tahun 2018-2010. Skripsi. Fakultas Ekonomi dan Bisnis. UIN. Jakarta.

Jafri, Hasan Effendi \& Elia Mustikasari. 2018. Pengaruh Perencanaan Pajak, Tunneling Incentive dan Aset Tidak Berwujud Terhadap Perilaku Transfer Pricing.Berkala akuntansi dan Keuangan Indonesia (BAKI), Vol. 03, No. 02, 2018: 63-77

Jensen, M. C and Meckling, W.H. .1976. Theory Of The Firm: Manajerial Behavior, Agenc Costs and Ownership Structure. Journal Of Financial Economics. Oktober, 1976. Vol.3, No. 4, pp. 305-360.

Jumaidi, Lalu Takdir, Bambang dan Robith Hudaya. 2017. Analisi Pajak, Tunneling, Gross Margin, dan KAP Spesialis Terhadap Keputusan Untuk Melakukan Transfer Pricing. JAA. Vol.1, No.2, April 2017.

Katadata.co.id. Gelombang Penghindaran Pajak Dalam Pusaran Batu Bara. (https://katadata.co.id/opini/2019/02/11/gelombang-penghindaran-pajak-dalampusaran-batu-bara). Diakses 21 Februari 2020.

Kasmir. 2012 . analisi Laporan Keungan. Jakarta: PT Raja Grafindo Persada.

Kurniawan, Anang Murry. 2015. Buku Pintar Transfer Pricing Untuk Kepentingan Pajak. Yogyakarta: Andi Offset.

Mangoting, Yenni, 2000, Aspek Perpajakan Dalam Praktek Transfer Pricing. Jurnal akuntansi dan Keuangan. Vol.2 No.1, Mei, hal. 6982.

Marfuah, \& Azizah, A.P.N. 2014. Pengaruh Pajak, Tunneling dan Exchange Rate, JAAI Volume 18 No.2, Desember 2014: 156:165

Mariska Ratna. 2017. Pengaruh Pajak, Bonus Plan, Tunneling Incentive dan Ukuran Perusahaan Terhadap Transfer Pricing. Vol.5 No.2, 2017

Mispiyanti. 2015. Pengaruh Pajak, Tunneling Incentive dan Mekanisme Bonus Terhadap Keputusan Transfer Pricing. Journal of Accounting and Investment. Vol. 16, No. 1, Januari 2015.

News.ddtc.co.id. Sektor Pertambangan Rawan Manipulasi Transfer Pricing. (https://news.ddtc.co.id/sektor-pertambangan-rawan-manipulasi-transfer-pricing17422? page y=440). Diakses 17 Februari 2020.

Nurlita, T. 2018. Pengaruh Debt Covenant, Tunneling Incentive, dan Intangible assets terhadap Keputusan Transfer Pricing Pada Perusahaan Mnufaktur. Fakultas Ekonomi dan Bisnis.

Noviastika, F, Yuniadi Mayowan, Suhartini Karjo.S 2016. Pengaruh Pajak, Tunneling Incentive dan Good Governance (GCG) Terhadap Indikasi Melakukan Transfer Pricing. Jurnal Perpajakan (JEJAK). Vol.8 No.1, 2016

Pernyataan Standar Akuntansi Keuangan (PSAK) Nomer 7 Tentang Pengungkapan PihakPihak ynag Mempunyai Hubungan Istimewa. 
Putri, Elsa Kisari. 2016 "Pengaruh Kepemilikan Asing, Ukuran Perusahaan, Dan”

Rahayu, Tri Tanjung. Endang Masitoh. Dan Anita Wijayanti. Pengaruh Pajak, Exchange Rate, Tunneling Incnetive, Profitabilitas dan Leverage terhadap keputusan Transfer Pricing. Jurnal Penelitian Ekonomin dan akuntansi (JPENSI). Volume 5 No. 1, Februari 2020.

Richardson, G. Taylor, G dan Lanis, R. 2013. Determinants of Transfer Pricing Aggressiveness: Empirical Evidence From Australian Firm. Journal of Contemporary Accounting \& Economics, 9, 136-150.

Saifudin dan Putri, Luki Septiani. 2017. Determinasi Pajak, Mekanisme Bonus, dan Tunneling Incentive Terhadap Keputusan Transfer Pricing. Agregat. Vol.2, Hal 32-43.

Saraswati, G.A.R.S dan Sujana, I sujana. 2017. Pengaruh Pajak, Mekanisme Bonus, dan Tunneling Incentive Pada Indikasi Melakukan Transfer Pricing. E-Jurnal akuntansi Universitas Udayana. Vol.19.2 Mei 2017: 1000-1029.

Santosa, Siti Jasmine Dwi \& Suzan Leny. 2018. Pengaruh Pajak, Tunneling Incentive dan Mekanisme Bonus Terhadap Keputusan Transfer pricing. Jurnal Kajian Akuntansi. Vol. 19. No 1.

Shodiq Ja'far, Kesi Widjayanti, dan Endang Rusdianti. 2017. Determinasi Keputusan Transfer Pricing. jurnal Riset Ekonomi dan Bisnis Universitas Semarang. Vol. 10, No.2.

Sumarsan Thomas. 2015. Tax Review dan strategi Perencanaan Pajak. Edisi 2, Jakarta: Indeks. Suandy, Erly. 2011. Perencanaan Pajak. Jakarta: Salemba Empat.

Sugiyono. 2017. Metodologi Penelitian Kuantitatif, Kualitatif dan Kombinasi (Mixed Methodd). Bandung. Alfabeta.

Suryatiningsih, Neneng, dan Sylvia Veronica Siregar. 2009. Pengaruh Skema Bonus Direksi Terhadap Aktivitas Manajemen Laba: Studi Empiris Pada BUMN periode Tahun 20032006. Jurnal Simposium Nasional Akuntansi 11. Solo.

Syahidatul Marfuah, Siti Nulela dan Anita Wijayanti. 2019. Beban Pajak, Nilai Perusahaan dan Exhange Rate dan Transfer Pricing Pada perusuhaan Pertambangan. Jurnal Ekonomi Paradigma Vol. 21 No.1, Juli 2019: ISSN: 1691-0827.

T, A, R, Nurhidayat \&. 2017. Pengaruh Pajak dan Mekanisme Bonus terhadap Keputusan Transfer Pricing. Vol 16 (18), 111-123

Undang-undang Nomer 36 tahun 2008 tentang Pajak penghasilan

Yuniasih, Wayan, Ni, Ketut Rasmini dan Gede Wirakusuma. 2012 Pengaruh Pajak Dan Tunneling Incentive Pada Keputusan Transfer Pricing Perusahaan Manufaktur Yang Listing Di Bursa Efek Indonesia. Jurnal Universitas Udayana. 